\title{
Faculty Perceptions Of Attendance Policy In An AACSB School
}

Jo Ann M. Pinto, Montclair State University, USA

Peter L. Lohrey, Montclair State University, USA

\begin{abstract}
The issue of attendance policies has been studied by higher education professionals for nearly a century. Prior research has shown a strong statistical link between class attendance and student grades. The aim of our research project is to gauge the attitudes and policies of business school professors in an AACSB accredited school on this topic. An online survey was conducted during the early Fall 2018 semester. Results suggest the vast majority of respondents institute an attendance policy in their classes. Respondents taught courses at both the graduate and undergraduate levels and are a diverse set of faculty as indicated by academic rank, age, gender and level of education.
\end{abstract}

Keywords: Attendance Policy; AACSB Faculty, Internal Survey

\section{INTRODUCTION}

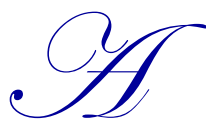

ccording to Crede, Roch and Kieszczynka (2010) attendance policies have been studied by academics at institutions of higher learning since at least 1927 . With nearly a century of research available to peruse, professors are split into two camps when it comes to implementing a mandatory attendance policy. These divergent viewpoints have recently been evident in both the academic and popular press.

In a 2017 essay entitled, "Why I Don't Take Attendance" Kelli Marshall, an instructor of media and cinema studies at DePaul University, explains how she changed her attitude regarding attendance after reading Murray Sperber's article, "Notes from a Career in Teaching." Sperber advocates against a mandatory attendance policy and lays out the argument, frequently cited in the literature, that students are emancipated and should be accountable for time management. Marshall also highlights the point that Sperber makes that student attendance should be seen as a referendum on the quality of instruction being offered.

In a somewhat opposing position, psychologist Jennifer L. Taitz, writing on the Op-Ed page of The Wall Street Journal, takes a strong pro-attendance stance in her piece entitled, "The Case Against Cutting Class." Her piece was published on August 16, 2018, just as a new academic year was beginning at most US colleges and universities. Taitz argues, from a mental-health point-of-view, that having a regular schedule and interacting with peers and professors can reduce the incidence of anxiety and depression which afflicts many college students today. She also makes the analogy that one would not pay a significant sum of money to attend an event and not show up which is tantamount to what happens when one skips class.

The aim of the current study is to gauge the attendance policies and perceptions of Business School faculty in an AACSB accredited institution located in the Mid-Atlantic region of the United States. The university is a public state school with both undergraduate and graduate degrees offered as well as a minor in business administration.

The rest of this paper is organized as follows. Section II provides an analysis of the extant literature. Section III lays out a theoretical framework and hypothesis development. Section IV explains the methodology and reports descriptive statistics. Section V reports the results of hypothesis testing. Section VI concludes with a discussion and avenues for future research. 


\section{LITERATURE REVIEW}

Much of the existing literature centers on several themes which appear throughout papers published on this topic. Specifically, they can be divided into several categories along the following lines: firstly, students are adults and should be accountable for their own behavior; secondly, students are consumers of their educations and, since they are paying, can decide if it worthwhile to attend class; and thirdly, a large literature is centered on analyzing the relationship between student presence and final outcomes. The extant literature has discussed these topics in engineering (Lowder et al., 2015), economics (Romer, 1993; Marburger, 2006), agricultural economics (Devadoss \& Foltz, 1996), nursing (Ruth-Sahd \& Schneider, 2014) and in a multi-disciplinary setting (Maurer et al., 2009). To date, this is the first known attempt to study faculty perceptions in an AACSB school of business across all academic departments.

\section{i. The Argument That Students Are Adults}

Up until the late 1960's, colleges and universities functioned in a manner known as in parentis loco or in place of the parent. Female dormitories often had a "house mother" who looked after the well-being of her residents. However, with the changes affecting college campuses around the time of the Vietnam War and the lowering of the voting age to 18 in 1972, students began to be seen as adults by both faculty and university administrators. Choice was expanded in many areas of university life including attendance policies. The debate rages on today with input from both students and faculty.

From the faculty point of view, it has already been stated that some instructors, i.e., Marshall, believe their students to be adults and should make their own decisions about attendance on any given day. This viewpoint is shared by Lohrey (2016) who also adds that if students are able to serve in the military, then society treats them as adults.

Students have also weighed in on the subject in various outlets. In a 2011 "Pro/Con" piece attendance polices, student Amanda Cox agrees with participation and attendance grades factored into a student's final grade. Taking the opposite tact, Zain Shammas states that, "The practice of grading based on attendance is unfair and should be abolished."

With the advent of computer-based learning management systems and professors posting their online, some feel even more strongly that information can be absorbed without physically attending class. Technology has allowed students to access course materials on demand in many classes with the exception of laboratory or studio courses.

\section{ii. Students Are Consumers of Their Educational Experience}

This argument has also received currency in the recent literature. Sam Artley, while a student at Michigan State University in 2012, feels that since students are paying tuition to attend classes, their class grade shouldn't be impacted by absenteeism. However, Ruth-Sahd and Schneider (2014), regarding absenteeism in nursing programs, believe this behavior can ultimately impact students' performance in a clinical setting where nurses are providing critical care to society at large. In this respect, it is not only the student but the public-at-large who consumes the value of the student's education.

Devadoss and Foltz (1996) use neoclassical economic theory to point out that students are both consumers and producers of the educational experience. As producers, they are ultimately measured by educational performance. Hence, from their viewpoint the student-as-consumer viewpoint alone runs counter to established economic theory. Furthermore, stakeholder theory would argue that many constituents, including taxpayers, donors, and Federal student aid distributors can also claim that they are at least partially the consumers of education as a societal good.

\section{iii. The Interaction Between Student Attendance and Class Standings}

The intersection between student attendance and final outcomes or GPA has received substantial attention in various literatures. Arguably the seminal work on this topic is a meta-analysis by Crede et al. (2010). They found that the relationship between class attendance and student outcomes actually surpassed such factors as high school GPA, SAT scores, and study habits. They conclude by finding a small impact between mandatory attendance policies and grades. 
In a recent article (2011) in The Chronicle of Higher Education Rae (2011) points out that some colleges and universities are putting a renewed emphasis on attendance as a way to tackle the twin objectives of increasing retention rates and graduation rates. The piece goes on to state that at Cal State's East Bay campus some faculty in first-year courses factor attendance into as much as 40 points towards a student's grade for the semester. This is relevant to retention studies since freshman year retention is the most critical year for retention rates.

Romer (1993) found that at elite universities on average 33\% of students were absent on any given day in an economics course. Given this finding, he decided to investigate the relationship between class attendance and outcome in the course. His finding, based upon a regression analysis, are as follows: " the point estimates imply that a student who attends only a quarter of the lectures on average earns a $1.79(\mathrm{C})$, while a student who attends all of the lectures on average earns a $3.44(\mathrm{~B}+)$. Attendance alone accounts for 31 percent of the variance in performance."

In another study produced by an economics professor, Marburger (2006) found that a compulsory attendance requirement, "significantly reduces absenteeism and improves exam performance." This significant finding is stronger than the relationship observed by Crede et al. (2010) when attendance is enforced.

The existing literature thus far delineates a strong relationship between attendance and student achievement as measured by final grades. If this relationship is so strong, why are attendance policies, whether they are mandatory or not, not advocated by all members of the academy? The answer to this may lie in the fact that some faculty believe this is up to the individual instructor and should not be institutionalized. This argument aligns with a strong belief in academic freedom.

\section{THEORETICAL FRAMEWORK AND HYPOTHESIS DEVELOPMENT}

This section lays out the hypothesis to be tested. The hypotheses were developed by gathering both theoretical and applied inferences from prior studies.

The first hypothesis to be tested is to determine if attendance policies correlate with gender. This is based upon the somewhat out-of-date notion that female faculty members are more concerned with teaching then with research output. This dates from the idea that female faculty members are glorified school teachers.

The first hypothesis is:

H1: There exist differences in attendance polices between male and female faculty members.

The second hypothesis to be tested is one which is based on an idea prevalent in the literature that college students are adults.

The second hypothesis is:

H2: There are differences in attendance policies based upon whether or not faculty view their students as adults.

The third hypothesis centers on the fact that some faculty are more concerned with research than with teaching. This is captured in the survey by asking respondents if they had release time for research activities.

The third hypothesis states:

H3: There are differences between faculty attendance policies based upon whether or not the faculty member has release time for research activities.

Finally, the fourth hypothesis centers on academic freedom and attendance policies. As pointed out in Marshall (2017) tenured faculty may feel more secure in their position and may have less incentive to have an attendance policy relative to untenured and contingent faculty. 
The fourth hypothesis states:

H4: There are differences in attendance policies between tenured and untenured faculty.

\section{METHODOLOGY AND DESCRIPTIVE STATISTICS}

In order to gauge the perceptions of the faculty at an AACSB school, an Institutional Review Board-approved survey was sent to all full and part-time faculty as of the Fall 2018 semester. The survey was conducted via Qualtrics and respondents were assured of their anonymity. Learning from Ruth-Sahd and Schneider (2014) that a survey sent late in the semester may not yield a high response rate, it was decided to send the survey out via e-mail from September 14, 2018 through October 2, 2018. The initial survey was sent along with four follow-up e-mails every five days to faculty who had not registered a response.

Out of a population of 236 active faculty, 79 responses were recorded yielding a response rate of $33 \%$. A few of the questions had response rates slightly less than 79 since not all respondents answered all questions. A response rate between $30 \%$ and $40 \%$ in an internal survey is considered a respectable yield. The survey consisted of 21 questions which solicited attitudes about attendance policies as well as demographic data.

Summary statistics of the questions related to the hypothesis testing are reported below. The response results for the full survey are listed in the appendix to this study.

Table 1. Summary Statistics

\begin{tabular}{l|c|c}
\hline \multicolumn{1}{c}{ Question } & Response & Percentage \\
\hline I have an attendance policy in my class: & Yes & $86 \%$ \\
\hline My gender is: & Male & $62 \%$ \\
\hline $\begin{array}{l}\text { I believe students are adults and should utilize their } \\
\text { own judgment regarding attendance: }\end{array}$ & Yes & Yes \\
\hline I have release time for research activities: & Yes & $67 \%$ \\
\hline I currently have tenure at my institution & & $52 \%$ \\
\hline
\end{tabular}

\section{EMPIRICAL RESULTS}

The following section reports the empirical results and hypotheses testing. A Pearson Chi-Squared test was run to test the validity of the underlying assumptions using SPSS software. Results are displayed below:

Table 2. Outcomes of Hypothesis Testing

\begin{tabular}{c|c|c|c}
\hline Hypothesis & $\begin{array}{c}\text { Pearson Chi-Square } \\
\text { Test Statistic }\end{array}$ & $\begin{array}{c}\text { Asymptotic Significance } \\
\text { (2-sided) }\end{array}$ & Hypothesis Supported? \\
\hline H1 & 1.353 & .508 & No \\
\hline H2 & 6.445 & .011 & Yes \\
\hline H3 & 7.854 & .020 & Yes \\
\hline H4 & 7.959 & .047 & Yes \\
\hline
\end{tabular}

The first hypothesis is not supported; i.e., there is no statistically significant relationship between gender and the likelihood of having an attendance policy.

The second, third and fourth hypothesis are all supported at conventional levels of significance. Regarding H2, those professors who believe students are adults also are less likely to have an attendance policy. In reviewing the results of the test of H3, faculty who are heavily involved in research are also less likely to have an attendance policy. Finally, once tenured, faculty are also less likely to have an attendance policy giving credence to Marshall's (2017) assertion. 


\section{DISCUSSION AND CONCLUSIONS}

The following study was undertaken to gauge faculty perceptions of an attendance policy at an AACSB accredited business school in the Mid-Atlantic region of a public university. Faculty from all disciplines within the school were invited to participate in the IRB-approved survey. One of the limitations of the study is that a convenience sample was drawn from the underlying population of business school faculty with teaching responsibilities during the Fall 2018 semester. However, the overall results suggest that attendance policies are an important component of the pedagogy of many faculty members.

An important point to emphasize is that this survey dealt with face-to-face learning. As will be seen in the appendix, most of the class sizes faculty teach have a maximum student capacity of forty students. In some large universities, faculty may not have the ability to take attendance in larger classroom settings. However, recent developments in technology may mitigate this factor.

Further research into this subject matter may survey students' perceptions of the pros and cons of an attendance policy at the same institution. Additionally, data can be collected in an IRB-approved study which correlates attendance with student grades.

Finally, based upon the prior literature, institutions of higher learning may want to re-evaluate their attendance policies to ensure students' success in both retention and time-to-degree.

\section{AUTHOR BIOGRAPHIES}

Jo Ann Pinto is currently an Associate Professor in the Department of Accounting \& Finance at Montclair State University where she has been employed since 1999. She holds a B.S. in Accounting from Virginia Polytechnic Institute and State University, an M.A. in Economics and an MBA in Accounting from Montclair State University and a Ph.D. in Accounting and Applied Economics from Rutgers University.

Her research interests are in the area of capital markets, taxation and economic development. Her publications have appeared in The CPA Journal, The Journal of Applied Business Research and the Journal of International Financial Management and Accounting, among others. Her teaching responsibilities include financial accounting, cost accounting, managerial accounting and financial statement analysis.pintoj@montclair.edu Montclair State University, 1 Normal Avenue, Montclair, NJ 07043.

Peter L. Lohrey is currently an Assistant Professor in the Department of Accounting \& Finance at Montclair State University where he has been employed since 2014. He holds a B.S. in Business Administration from the University of Delaware, a MBA and M.S. in Finance from Loyola University Maryland and Ph.D. in Accounting and Finance from George Washington University.

His research interests are in the areas of business valuation, forensic accounting and fair value financial reporting. His publications have appeared in The CPA Journal, The Journal of Forensic \& Investigative Accounting, The Business \& Law Journal, and The American Journal of Management, among others. His teaching responsibilities include business valuation, forensic accounting, fraud examination and financial accounting. lohreyp@montclair.edu Montclair State University, 1 Normal Avenue, Montclair, NJ 07043.

\section{REFERENCES}

Barlow, J. \& Fleischer, S. (2011). Student absenteeism: whose responsibility? Innovations in Education and Teaching International, 48(3), 227-237.

Cox, A. \& Shammas, Z. (2011, April 11). Debate: Attendance-based grades are fair to students. The Sundial.

Crede, M., Roch, S.G., \& Kieszczynka, U.M. (2010). Class attendance in college: a meta-analyticr eview of the relationship between class attendance with grades and student characteristics. Review of Educational Research, 80(2), 272-295.

Devadoss, S. \& Foltz, J. (1996). Evaluation of factors influencing student class attendance and performance. American Journal of Agricultural Economics, 78, 499-507.

Golding, J.M. (2011). The role of attendance in lecture classes: You can leas a horse to water... Teaching of Psychology, 38(1), 
$40-42$.

Green, R.J. (2007, January 1). On taking attendance. Observer.

Hall, M. (2014, July). Should you require attendance? The Innovative Instructor.

Keith, N.K., Burnett, M.S, Pettijohn, C.E., \& Gilbert, P.S. (2005). A comparison of professor and student viewpoints regarding attendance and excused absences. Journal for Advancement of Marketing Education, 7(Winter), 47-57.

Lowder, L., Khalid, A.,. Ferreira, D.R., Bohannon, J.L., Stutzmann, B., Atiqullah, M.M., Singh, R., ... Colebeck, D. (2015). Student and faculty perceptions of attendance policies at a polytechnic university. $122^{\text {nd }}$ American Society for Engineering Education Conference \& Exposition, Seattle, WA, June 14-17.

Marburger, D.R. (2006). Does mandatory attendance improve student performance? Journal of Economic Education, Spring, $148-155$.

Marshall, K. (2017, October 13). Why I don't take attendance. Chronicle Vitae.

Maurer, T.W., Frost, L., Sturges, D., Charles, S., Allen, D., Cawthorn, M., \& Brewton, C.C. (2009). Faculty and student perceptions of post-exam attendance. Journal of the Scholarship of Teaching and Learning, 9(3).

Osman, R. (2012, March 25). Should class attendance be mandatory? Students, professors say no. Campus Life News for College Students, USA Today College.

Petress, K.C. (1996). The dilemma of university undergraduate student attendance policies: to require class attendance or not. College Student Journal, 30(3).

Pinto, J., Lohrey, P. (2016). Point-Counterpoint: Should Attendance Be Required in Collegiate Classrooms? Contemporary Issues in Education Research, 9(3), pp. 115-120.

Rae, T. (2011). Just showing up: educators focus on attendance to help students succeed. The Chronicle of Higher Education.

Rocca, K.A. (2004). College student attendance: impact of instructor immediacy and verbal aggression. Communication Education, 53(2), 185-195.

Romer, D. (1993). Do students go to class? Should they? Journal of Economic Perspectives, 7(Summer), 167-174.

Ruth-Sahd., L.A. \& Schneider, M.A. (2014). Faculty and student perceptions about attendance policies in baccalaureate nursing programs. Nursing Education Perspectives, May/June, 162-166.

Slater, T. (2016). Ready to revise your class attendance policy? The Society for College Science Teachers.

Snyder, J. \& Frank, L.A.C (2016). Attendance policies, instructor communication, student attendance and learning. Journal of Education for Business, 91(2), 108-116.

Sperber, M. (2005). Notes from a career in teaching. The Chronicle of Higher Education

Taitz, J.L. (2018, August 16). The case against cutting class. The Wall Street Journal, A-13. 


\section{APPENDIX: RESULTS OF FULL ONLINE SURVEY}
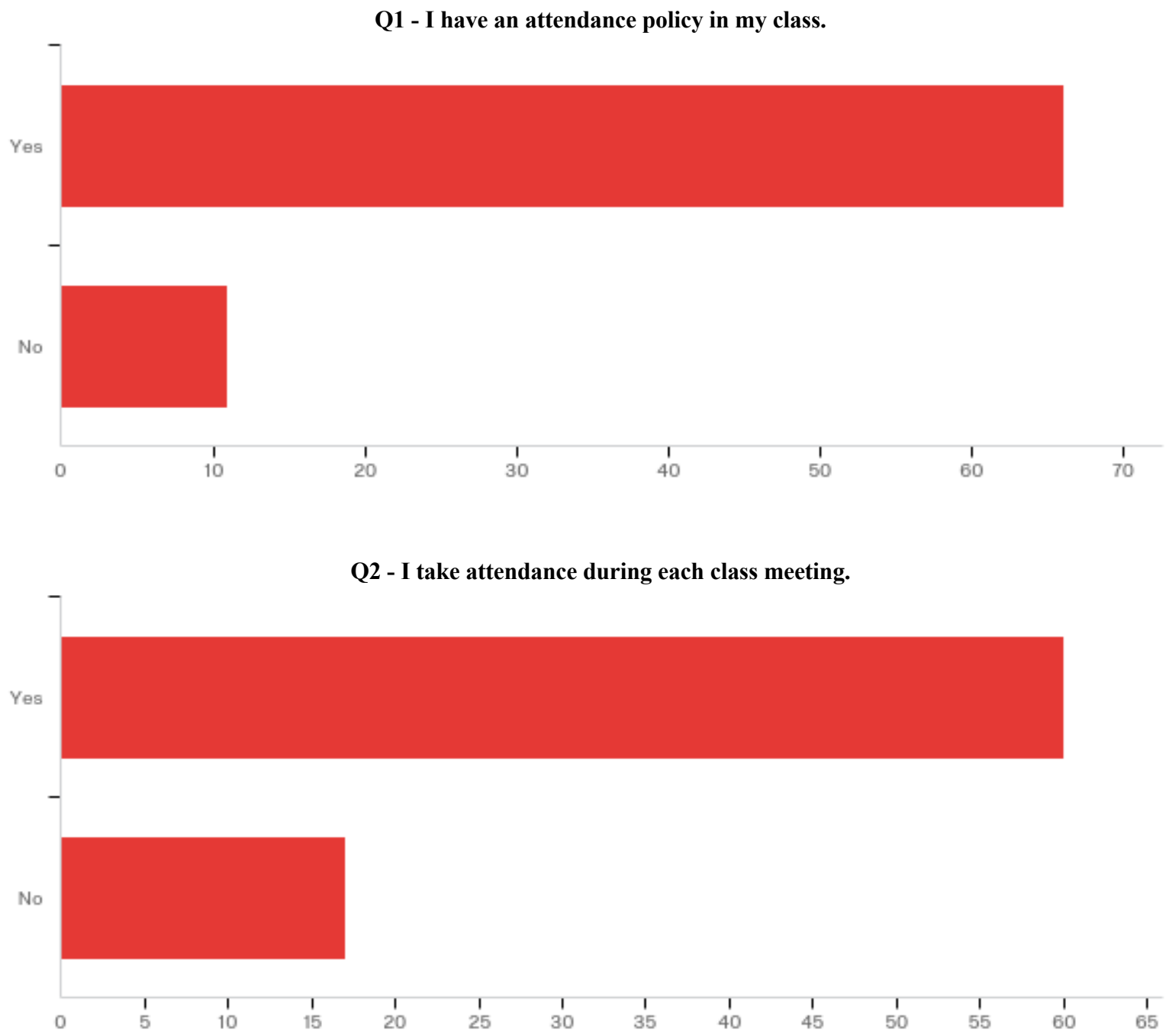
Q3 - Attendance is factored into students' final grade.

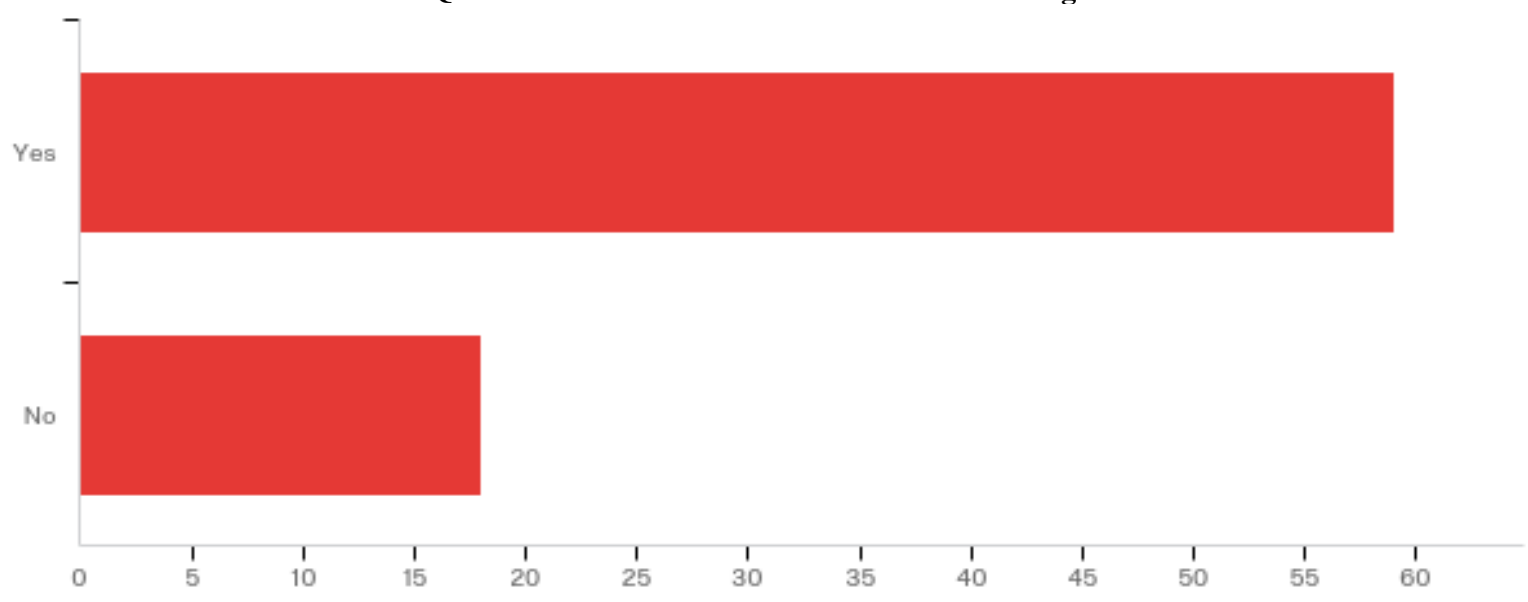

Q4 - If you answered "yes", what is the percentage that attendance (and participation) impacts final grade?

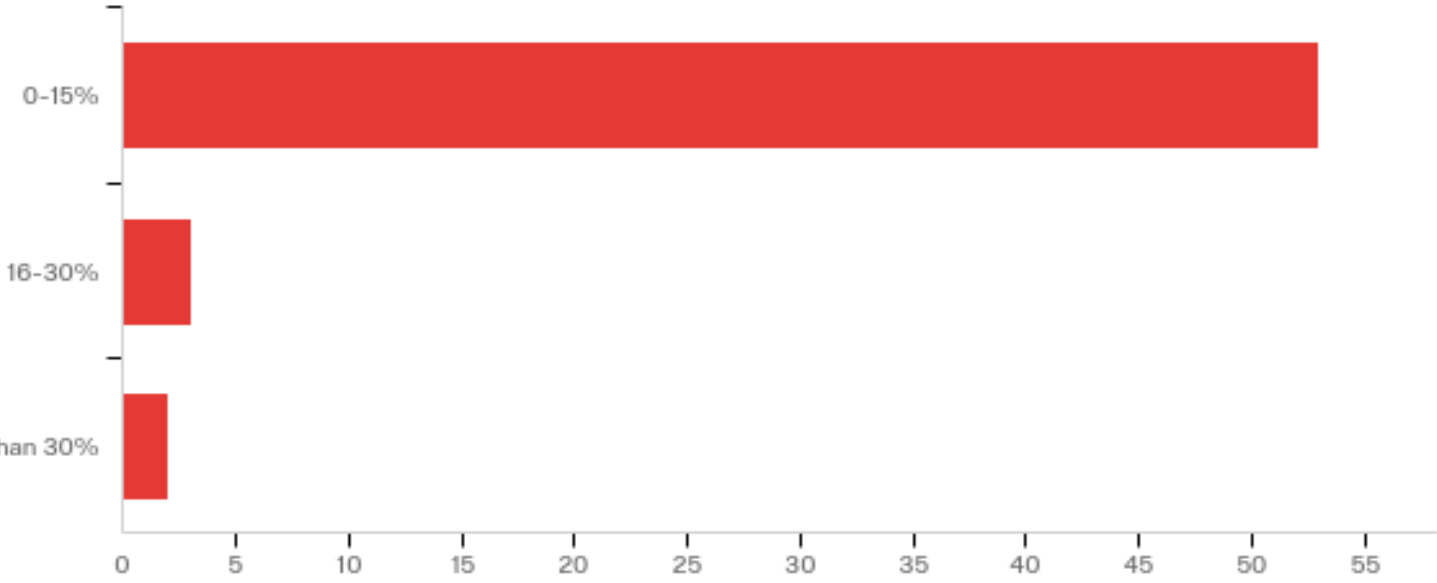

Q5 - I have read the University's policy regarding attendance.

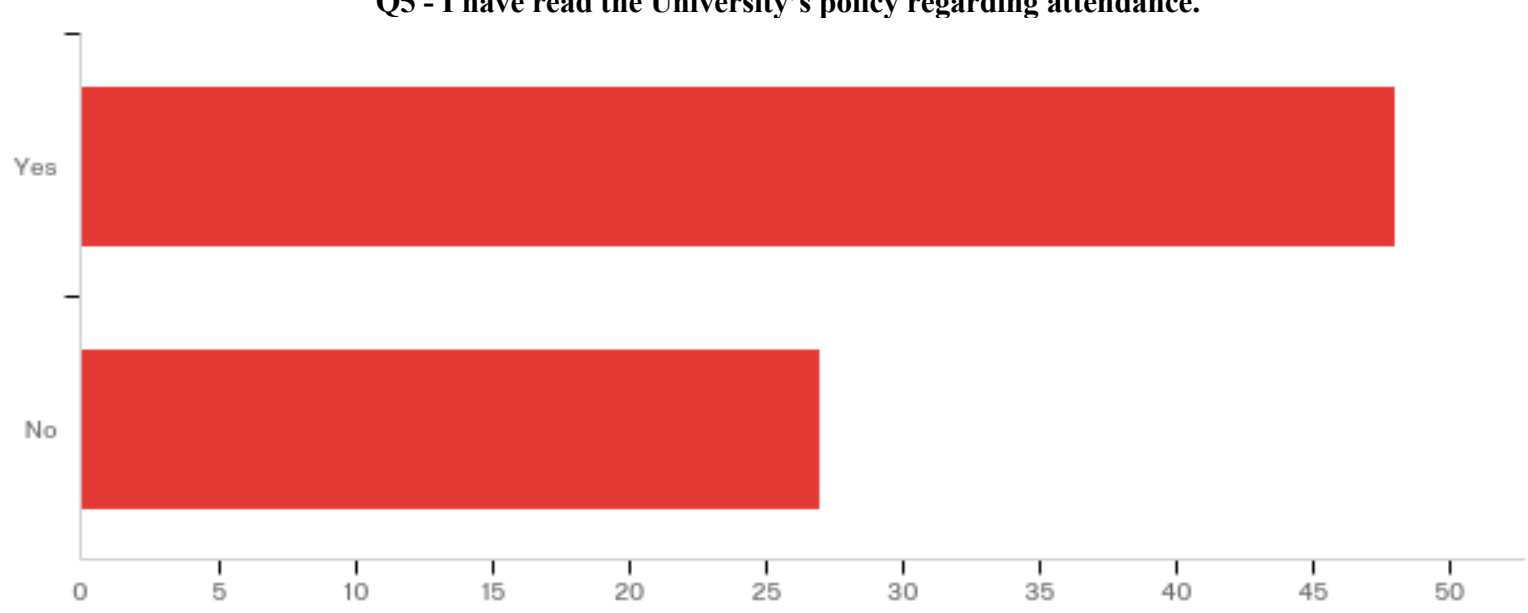


Q6 - I only take attendance during preliminary class meetings to comply with the Provost's requirement for enrollment verification.

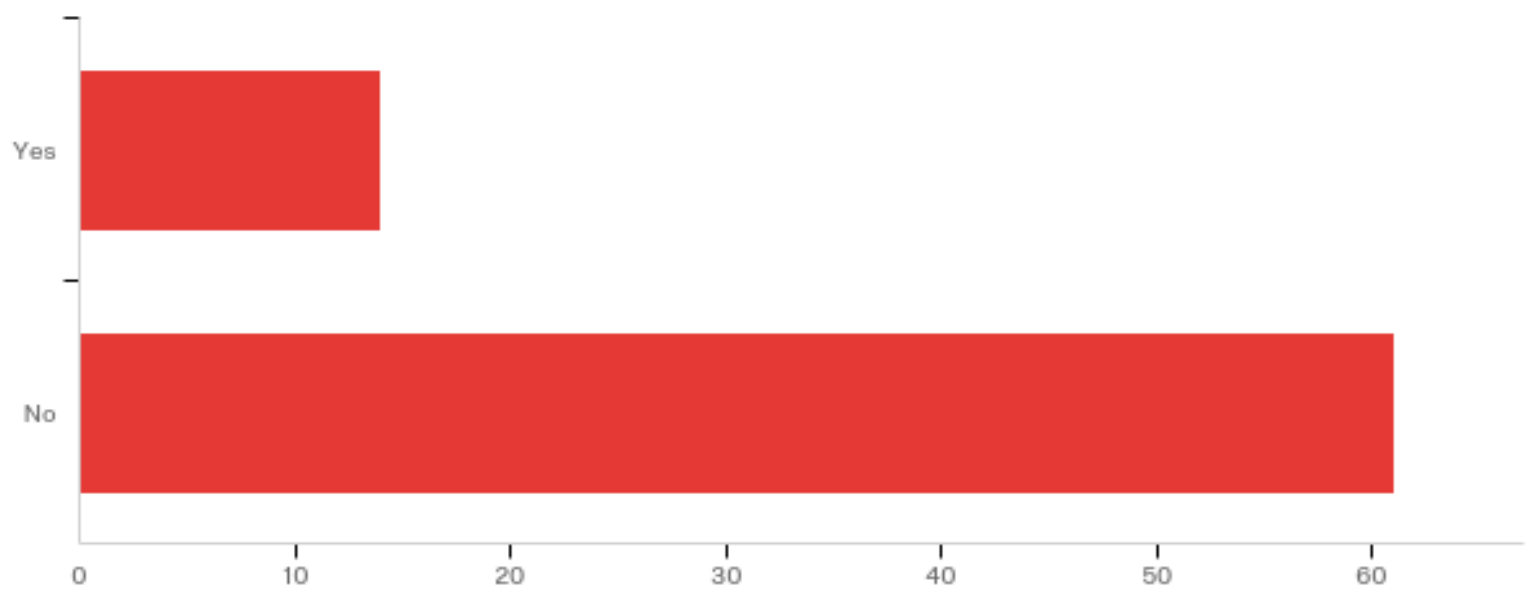

Q7 - I believe students are adults and should utilize their own judgment regarding attendance.

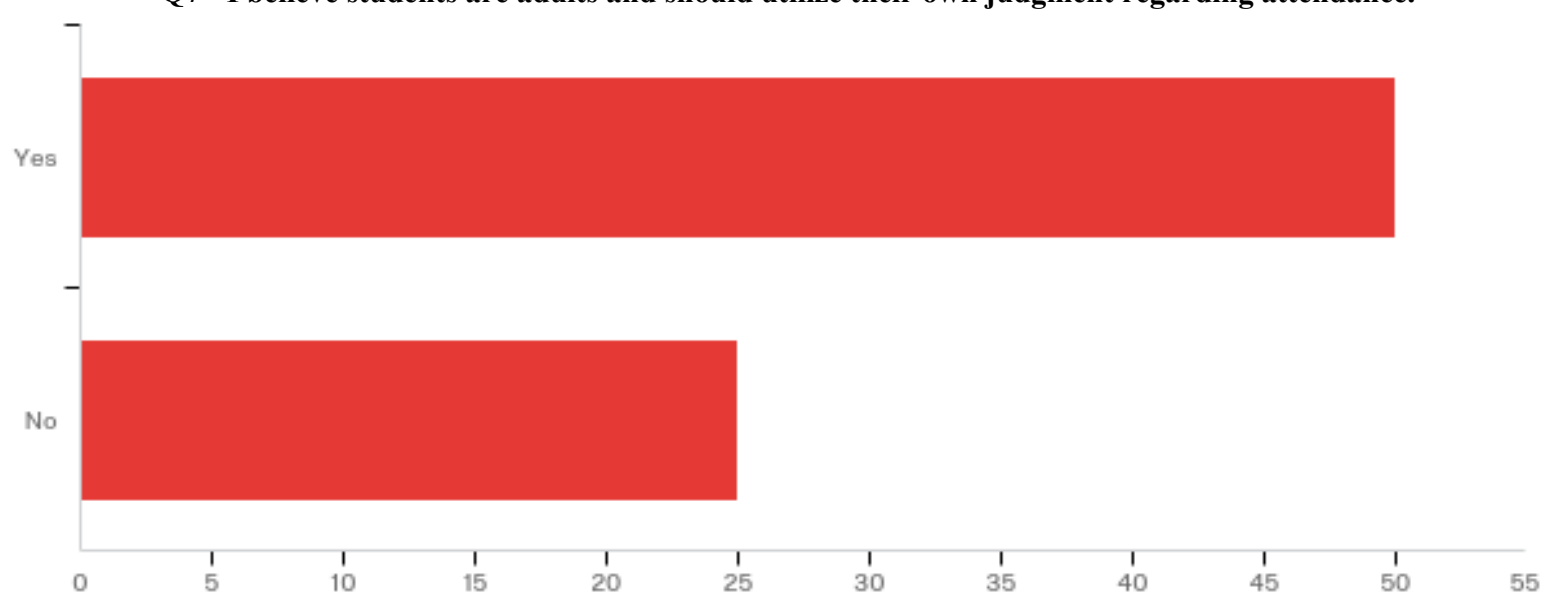

Q8 - I require attendance for all exams/quizzes/presentations.

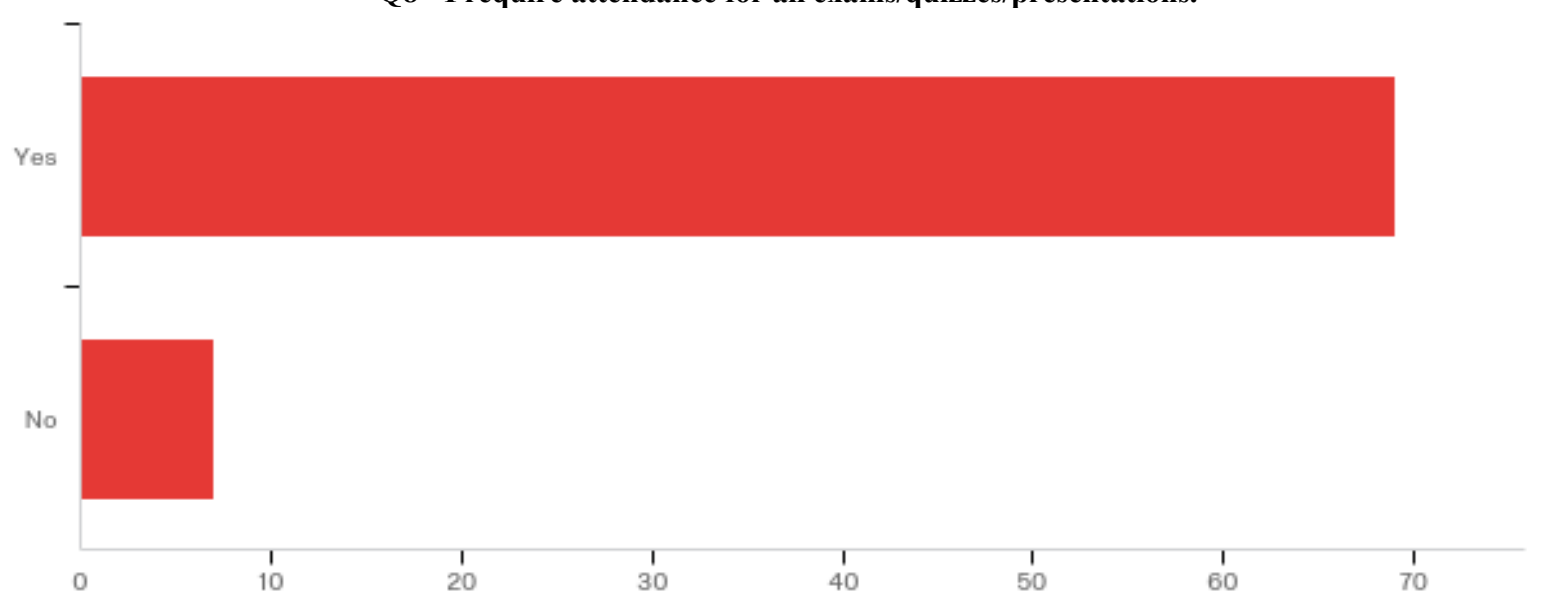


Q9 - I post all my lecture notes/PowerPoints on Canvas.

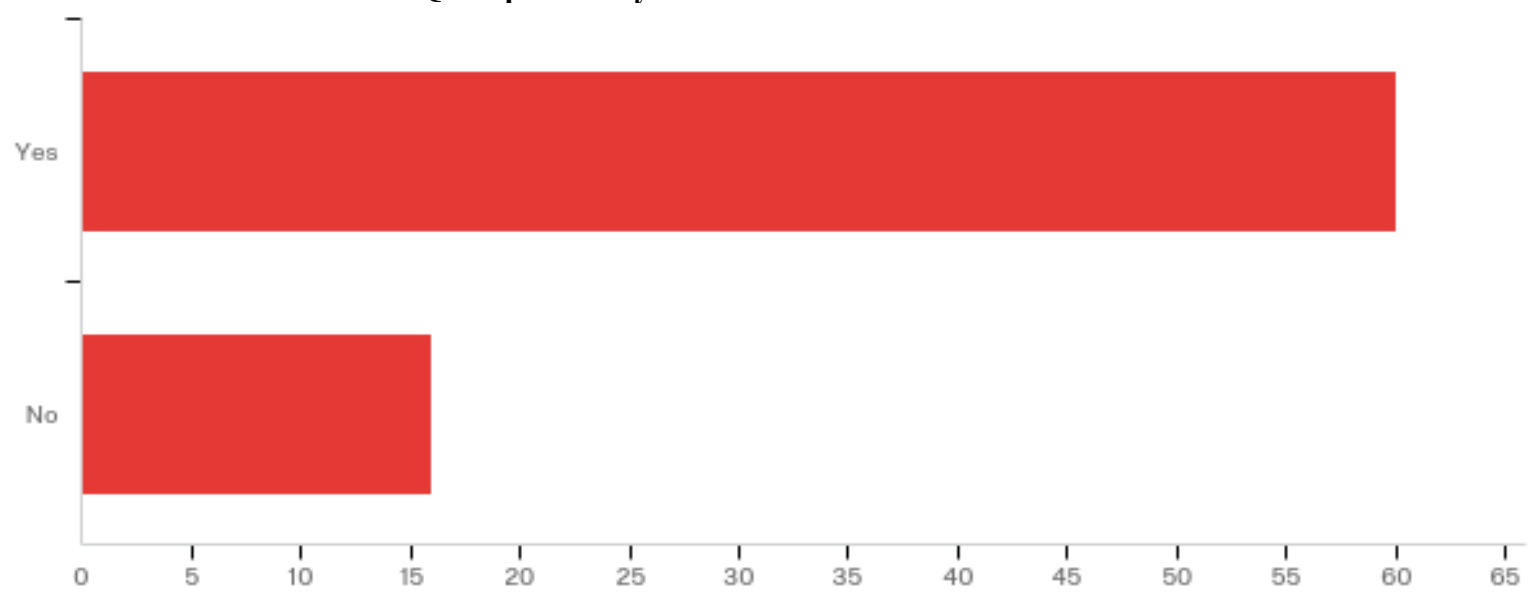

Q10 - My exams and other methods of evaluation are closely correlated with class lectures.

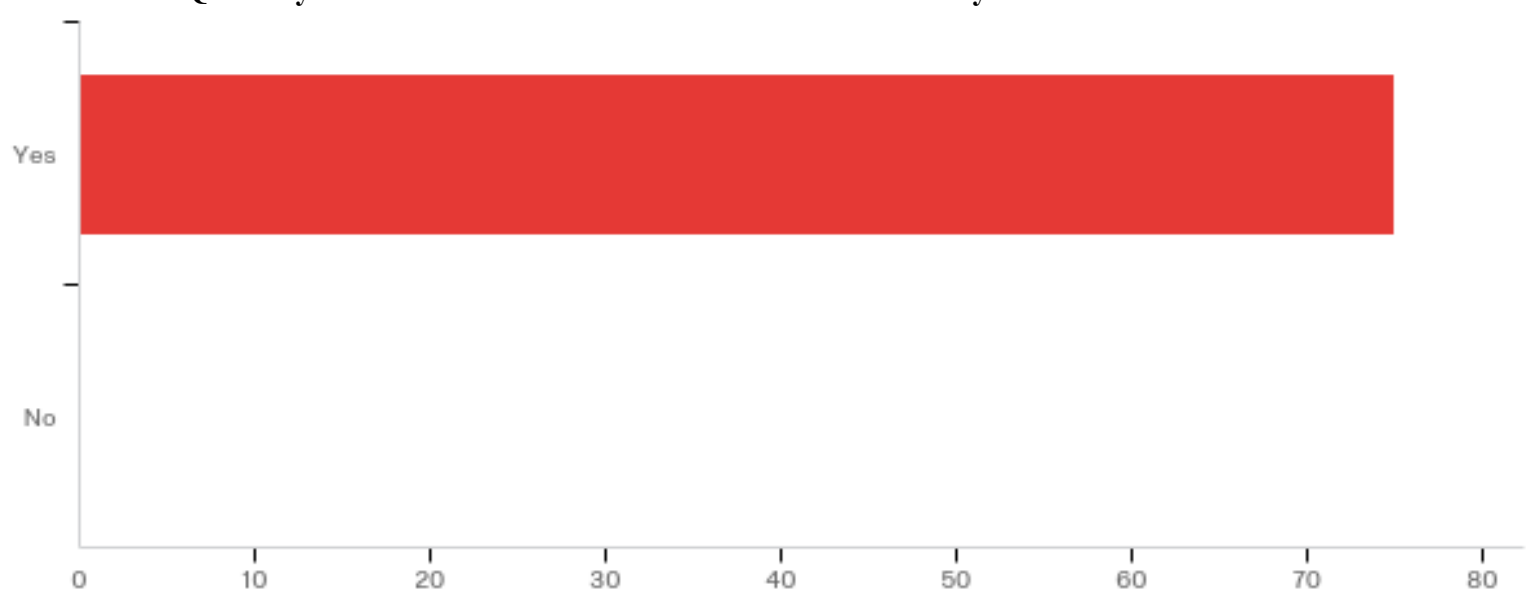



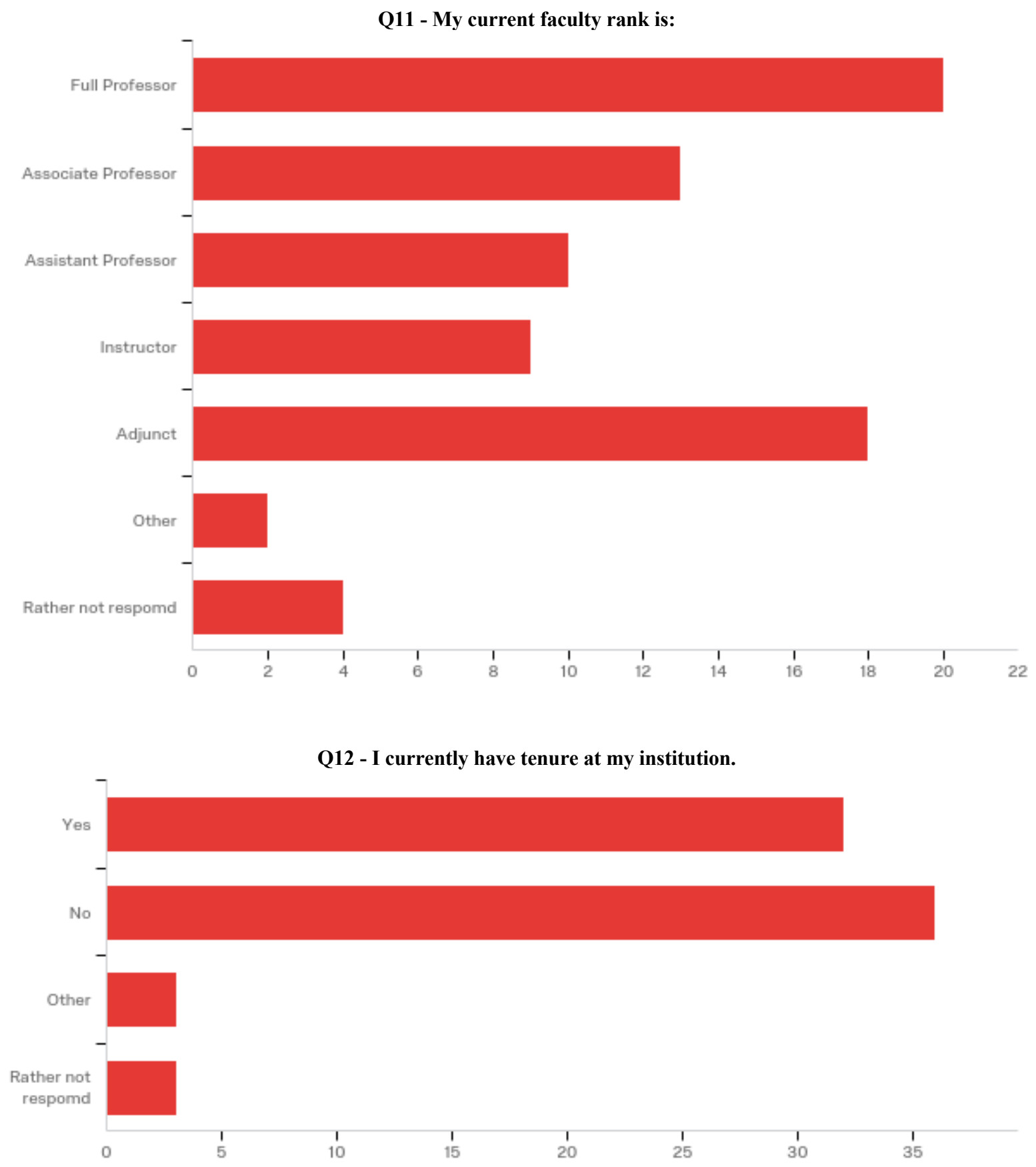

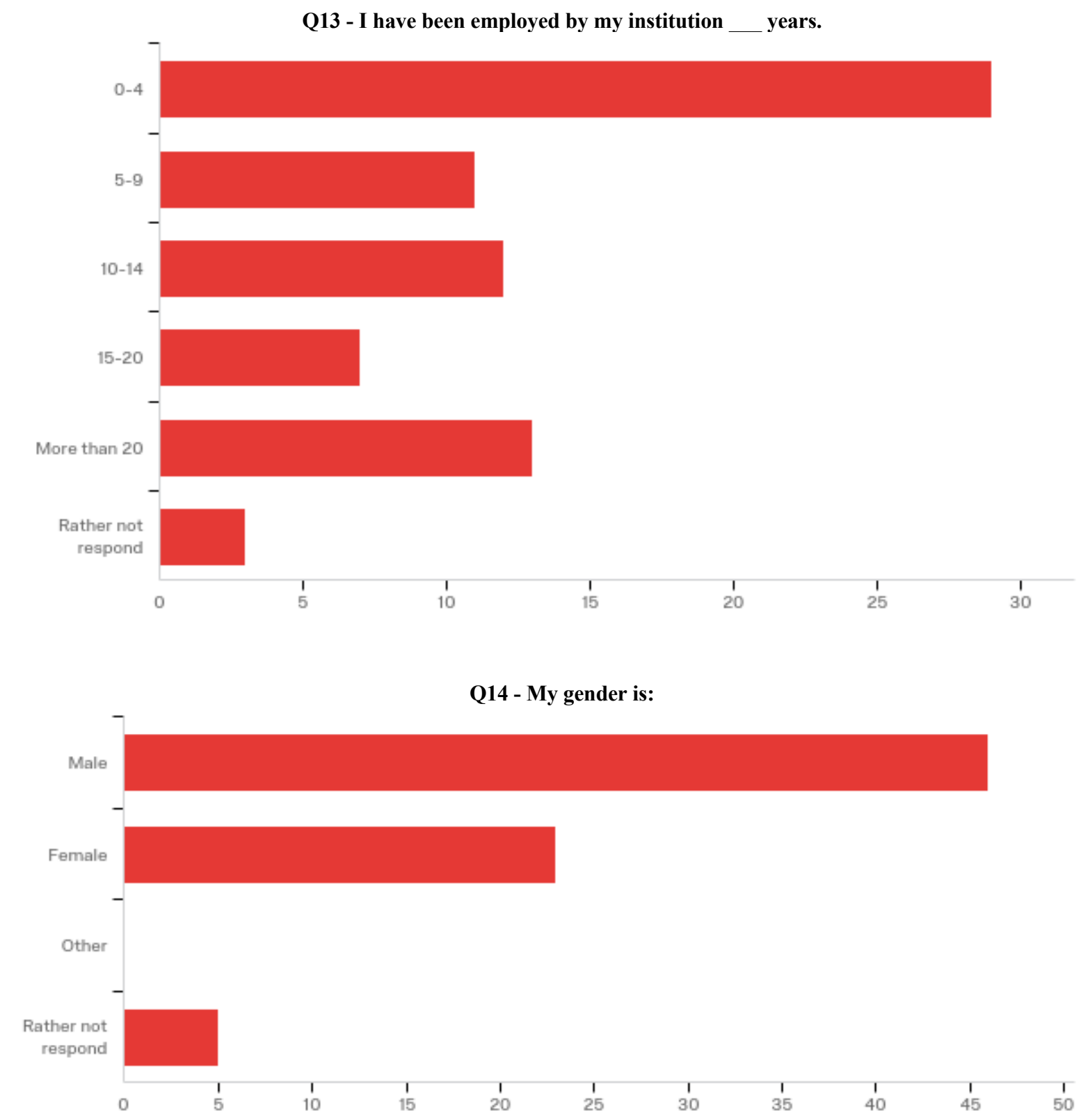
Q15 - The highest level of education I have attained is:
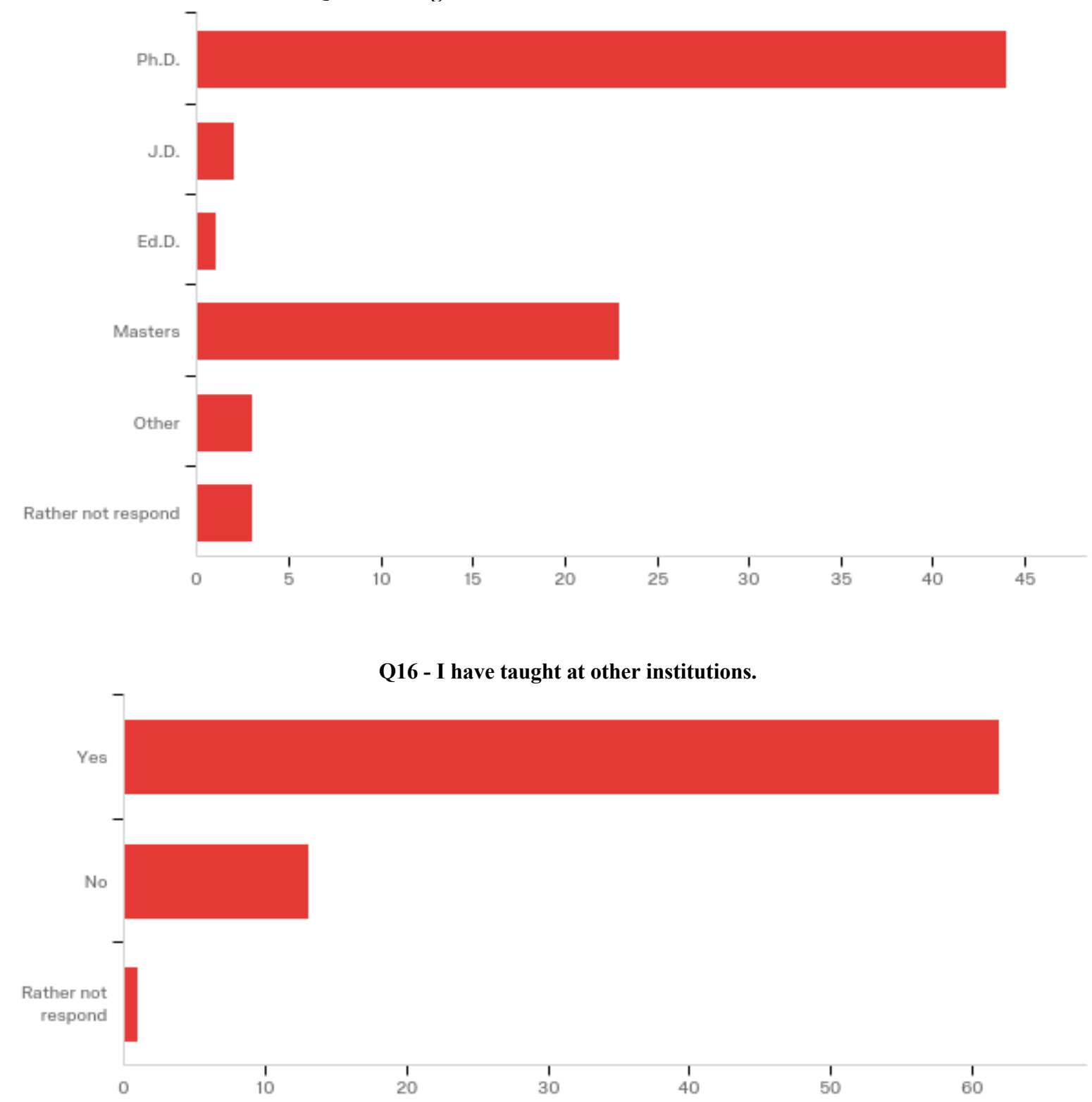

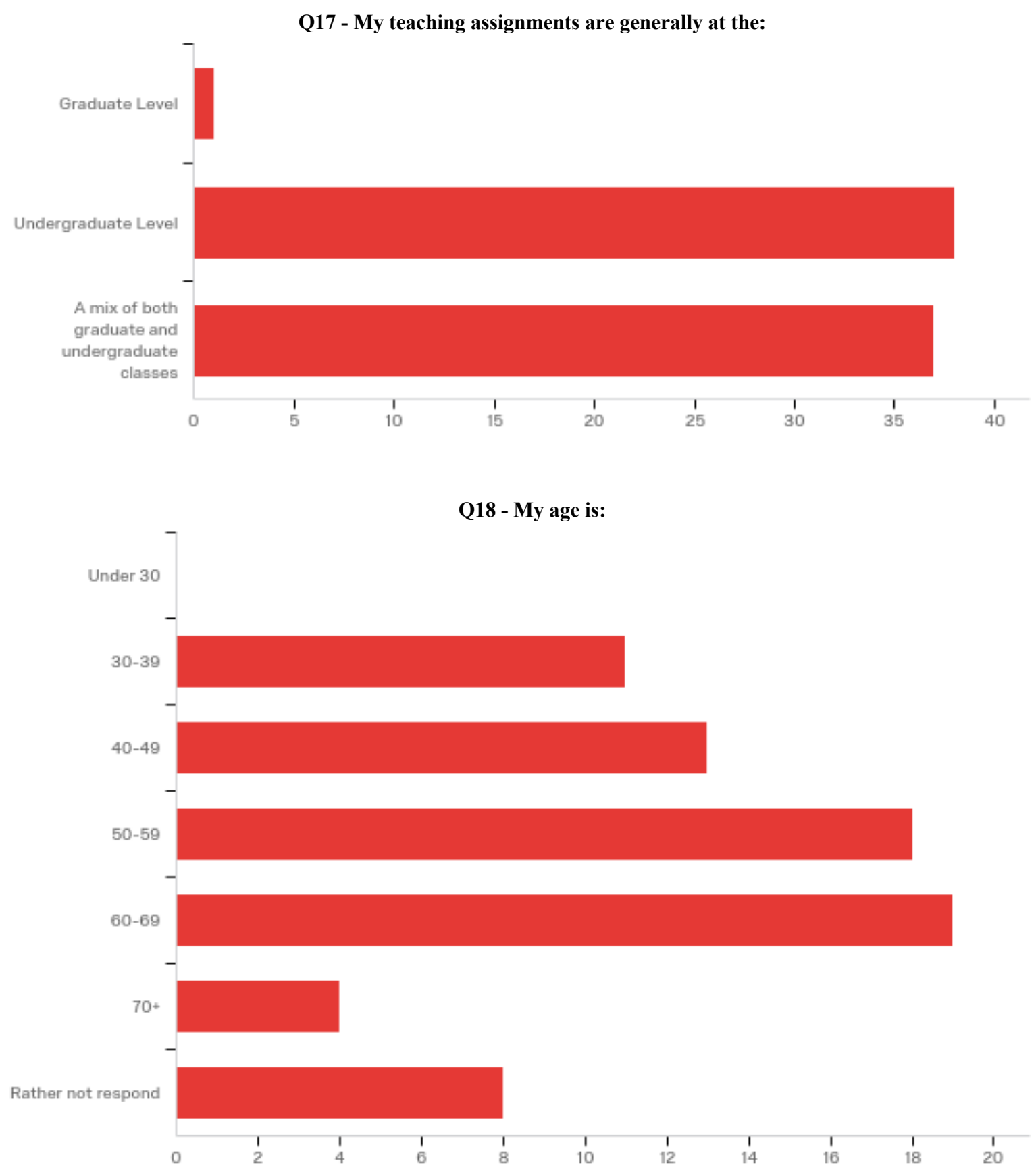

students.
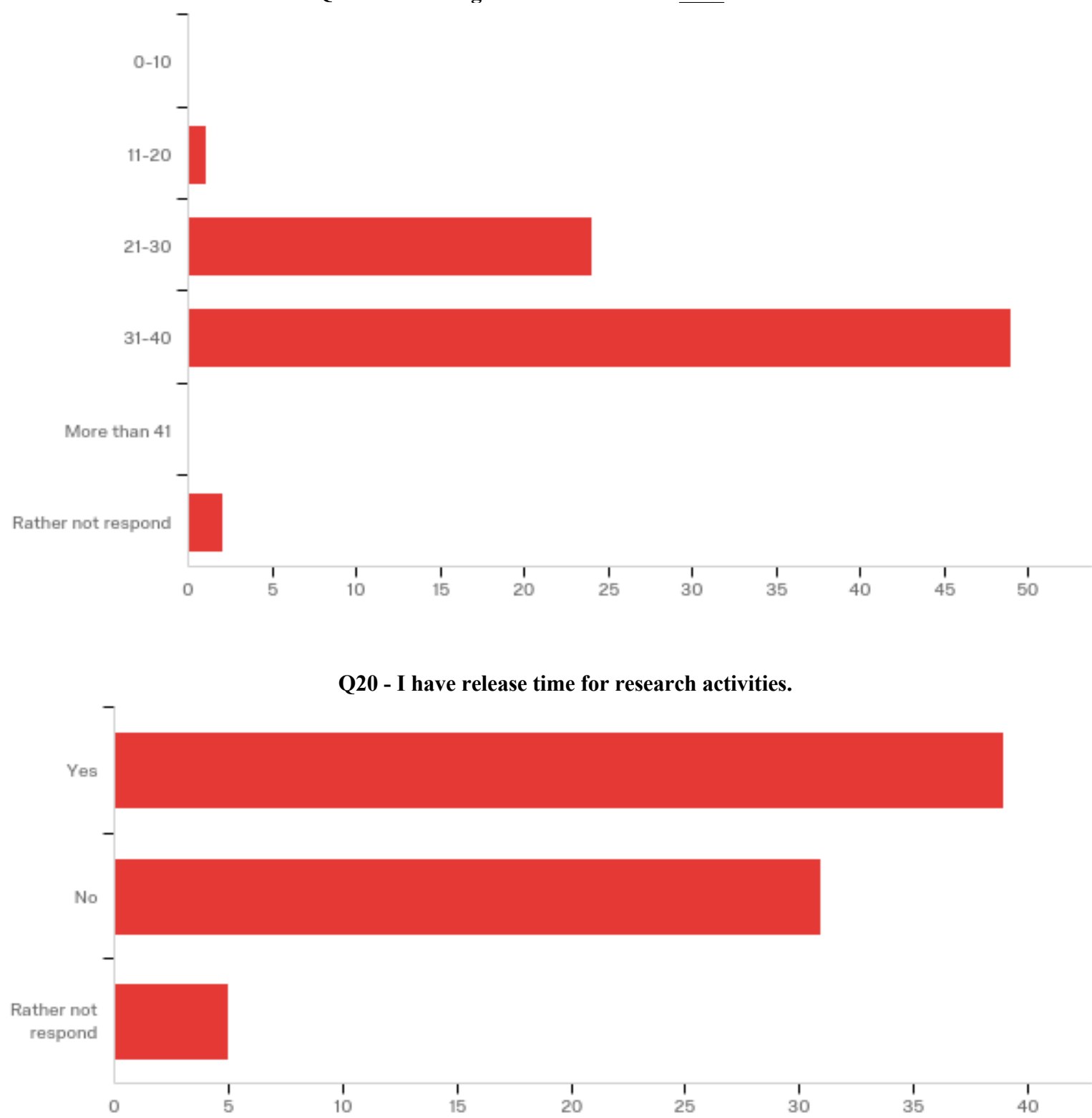


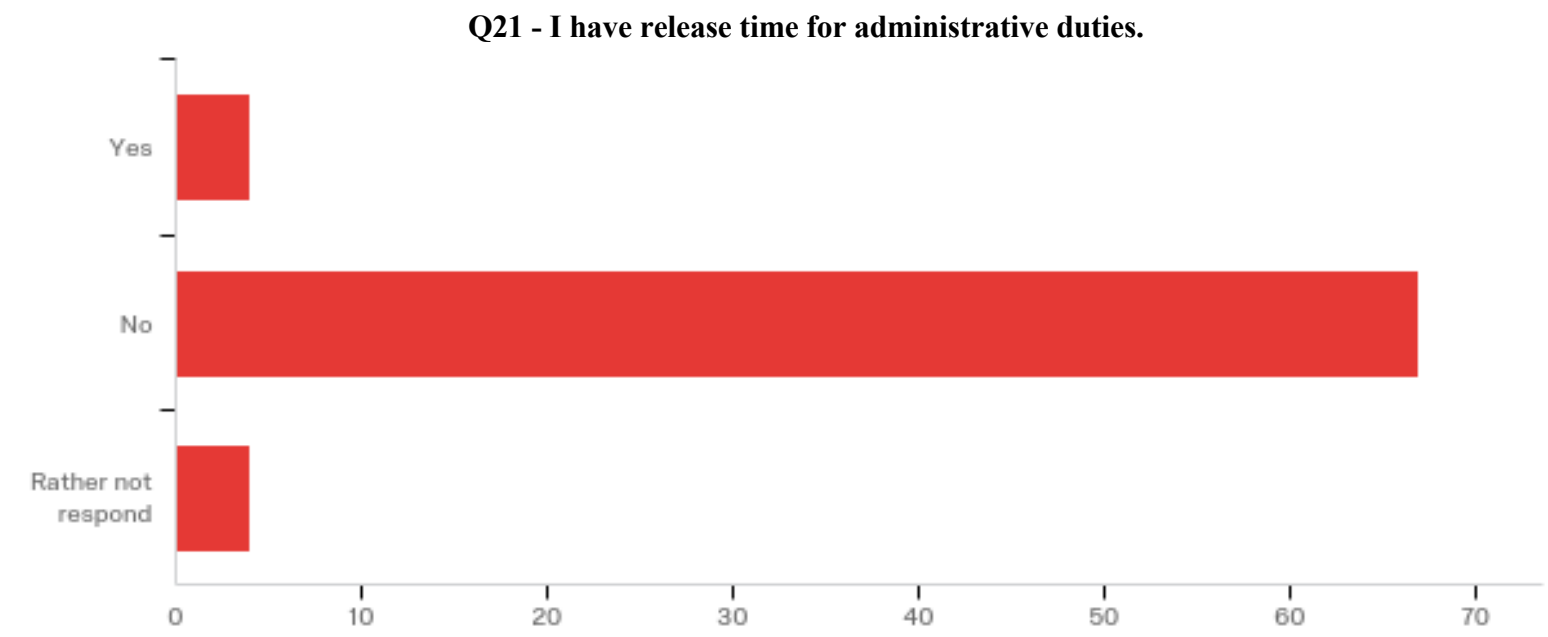

